\title{
Sensitive and Specific Detection of Xanthomonas oryzae pv. oryzae by Real- Time Bio-PCR Using Pathovar-Specific Primers Based on an rhs Family Gene
}

\author{
Min Seok Cho, Man Jung Kang, Chang Kug Kim, Young-Joo Seol, Jang Ho Hahn, Soo Chul Park, and Duk Ju Hwang, \\ National Academy of Agricultural Science, Rural Development Administration, 441-707 Suwon, Republic of Korea; Tae-Young Ahn, \\ Department of Microbiology, Dankook University, Cheonan 330-714, Republic of Korea; and Duck Hwan Park and Chun Keun Lim, \\ Division of Bio-resources Technology, College of Agriculture and Life Sciences, Kangwon National University, Chuncheon 200-701, \\ Republic of Korea; Dong Suk Park, National Academy of Agricultural Science, Rural Development Administration, 441-707 Suwon, \\ Republic of Korea
}

\begin{abstract}
Cho, M. S., Kang, M. J., Kim, C. K., Seol, Y.-J., Hahn, J. H., Park, S. C., Hwang, D. J., Ahn, T.-Y., Park, D. H., Lim, C. K., and Park, D. S. 2011. Sensitive and specific detection of Xanthomonas oryzae pv. oryzae by real-time bio-PCR using pathovar-specific primers based on an rhs family gene. Plant Dis. 95:589-594.

The present study describes bio-polymerase chain reaction (PCR) assays to detect bacterial leaf blight caused by Xanthomonas oryzae pv. oryzae in rice. Successful control of $X$. oryzae. pv. oryzae requires a specific and reliable diagnostic tool. However, other $X$. oryzae pathovars are detected by currently available molecular and serological methods. In this study, SYBR Green real-time and conventional PCR primer sets were designed based on an rhs family gene of $X$. oryzae $\mathrm{pv}$. oryzae KACC10331 because these genes are structurally diverse. The

isolates of two X. oryzae pathovars, 21 other Xanthomonas species, and 4 other reference phytopathogenic bacteria and fungi. The assay was also able to detect at least two genome equivalents of cloned amplified target DNA using purified DNA. Thus, the SYBR Green real-time PCR-based method can be used for the rapid and specific detection of $X$. oryzae pv. oryzae and will potentially simplify and facilitate diagnosis and monitoring of this pathogen and guide plant disease management.
\end{abstract} specificity of the primers was evaluated using purified DNA from 11
Bacterial blight caused by Xanthomonas oryzae pv. oryzae is the major rice disease in all tropical and subtropical Asian countries. The disease commonly produces leaf blight symptoms, and the pathogen invades the host tissue through leaf hydathodes or through mechanical injuries of the leaf blades and multiplies in the vascular system. Yield losses of 10 to $20 \%$ are common, and losses of 50 to $70 \%$ have been recorded in severely infected fields $(9,10,14)$. The control of bacterial blight is difficult, and the only practical methods for disease management rely on appropriate culture practices and the use of pathogen-free seed and resistant cultivars. Therefore, the specific detection of this pathogen in seed and plants is essential for effective disease control $(16,21)$. Diagnosis of $X$. oryzae pv. oryzae infection is based on isolation of the pathogen, followed by biochemical identification, pathogenicity tests, or serological tests consisting of fatty acid and other metabolic profiling $(2,3,5,19)$.

Currently, molecular assays based on repeated element, siderophore receptor gene, and 16S-23S rDNA spacer region are widely used for the detection of $X$. oryzae pv. oryzae strains but there have been critical defects in the diagnosis and identification of $X$. oryzae pv. oryzae isolates, in that these assays also detect $X$. oryzae pv. oryzicola $(1,7,16,21)$.

Therefore, in this study, a pathovar-specific primer set based on the rhs family gene of $X$. oryzae pv. oryzae KACC 10331 was designed. It was reported that $R h s$ repertoires (YD repeat proteins) are highly dynamic among enterobacterial genomes, due to repeated gene gains and losses. In contrast, the primary structures of rhs genes are evolutionarily conserved, indicating that $r h s$ sequence diversity is driven not by rapid mutation but by the rela-

Corresponding author: D. S. Park, E-mail: dspark@rda.go.kr

Accepted for publication 14 January 2011.

doi:10.1094/PDIS-06-10-0399

(C) 2011 The American Phytopathological Society tively slow evolution of novel core-and-tip combinations. However, the function of these proteins is unknown and the conditions under which they are expressed have also been difficult to define (4).

This article describes the design of specific polymerase chain reaction (PCR) primers that distinguish $X$. oryzae pv. oryzae from other xanthomonads and the optimization of protocols for detection of $X$. oryzae pv. oryzae from plants.

\section{Materials and Methods}

Bacterial strains and culture conditions. Bacterial and fungal strains were obtained from the Korean Agricultural Culture Collection (KACC) in the Republic of Korea, the Ministry of Agriculture, Forestry and Fisheries of Japan, the Belgian Coordinated Collections of Micro-organisms, the Deutsch Sammlung von Mikroorganismen und Zellkulturen $\mathrm{GmbH}$ in Germany, and the American Type Culture Collection. All microorganisms used in this study are listed in Table 1. Xanthomonas strains were cultured on YGC medium $\left(2.0 \% \mathrm{D}-(+)\right.$-glucose, $2.0 \% \mathrm{CaCO}_{3}, 1.0 \%$ yeast extract, and $1.5 \%$ agar) at $28^{\circ} \mathrm{C}$ for 2 days, Escherichia coli on Luria-Bertani agar (17) at $37^{\circ} \mathrm{C}$ for $18 \mathrm{~h}$, and other microbes on nutrient agar (Difco Laboratories) or potato dextrose agar (Difco Laboratories) at 26 to $28^{\circ} \mathrm{C}$ for 1 to 3 days.

DNA extraction. Xanthomonas strains were cultured on YGC medium and harvested with a scraper for total DNA extraction, which was prepared as described (6). Total DNA from other microorganisms was prepared using a genomic DNA extraction kit (Genomic-tips; Qiagen, Hilden, Germany).

Primer design and conventional PCR. Two primer sets were designed for an rhs family gene of $X$. oryzae pv. oryzae KACC10331 (GenBank accession no. NC_006834, gi|58579623: 124816-125631), with predicted PCR products of 114 and $290 \mathrm{bp}$ (Table 2). Conventional PCR assays were performed with a PTC225 thermocycler (MJ Research, Watertown, MA). All amplifications were carried out in a final volume of $50 \mu$ containing 10 $\mathrm{mM}$ Tris- $\mathrm{HCl}, 50 \mathrm{mM} \mathrm{KCl}, 1.5 \mathrm{mM} \mathrm{MgCl} 2,0.01 \%$ gelatin, 0.2 $\mathrm{mM}$ each dNTP, $10 \mathrm{pM}$ of each primer, 2 units of Taq polymerase (Promega Corp., Madison, WI), and approximately $50 \mathrm{ng}$ of 
genomic DNA from a given microorganism. Reactions were run for 25 cycles, each consisting of $60 \mathrm{~s}$ at $94^{\circ} \mathrm{C}, 30 \mathrm{~s}$ at $56^{\circ} \mathrm{C}$ (for the $\mathrm{XOO} 290$ primer set), and $60 \mathrm{~s}$ at $72^{\circ} \mathrm{C}$, with an initial denaturation of $5 \mathrm{~min}$ at $94^{\circ} \mathrm{C}$ and a final extension of $10 \mathrm{~min}$ at $72^{\circ} \mathrm{C}$. A $10-\mu \mathrm{l}$ aliquot of each amplified PCR product was electrophoresed on a $1.5 \%$ agarose gel, stained with ethidium bromide, and visualized with a UV transilluminator. For the amplification of insertion sequence (IS1113) region, the primers and reaction conditions were described as by Sakthivel et al. (16).

Specificity and sensitivity of the SYBR Green real-time PCR assay. The SYBR Green real-time PCR assay was performed in a
20- $\mu$ l reaction volume containing iQ SYBR Green Supermix (BioRad Laboratories, Inc., Hercules, CA). Each PCR reaction contained $10 \mu \mathrm{l}$ of iQ SYBR Green Supermix and 10 pmol each of $\mathrm{XOO} 114 \mathrm{~F} / \mathrm{R}$ and $5 \mathrm{ng}$ of purified DNA from each sample. Amplification was carried out using the CFX96 real-time PCR system (Bio-Rad Laboratories, Inc.), and the thermal cycling parameters were as follows: $95^{\circ} \mathrm{C}$ for $3 \mathrm{~min} ; 45$ cycles of $95^{\circ} \mathrm{C}$ for $10 \mathrm{~s}$ and $60^{\circ} \mathrm{C}$ for $20 \mathrm{~s}$; and a melting curve of 65 to $95^{\circ} \mathrm{C}$ with an increment of $0.5^{\circ} \mathrm{C}$. A copy number of the cloned DNA was calculated with the following equation $(20)$ : copies $/ \mu l=[6.022 \times$ $10^{23}($ copy $/ \mathrm{mol}) \times$ amount $\left.(\mathrm{g})\right] /[$ length $(\mathrm{bp}) \times 660(\mathrm{~g} / \mathrm{mol} / \mathrm{bp})]$. For

Table 1. Bacterial and fungal strains used in specificity tests of conventional and real-time polymerase chain reaction assays ${ }^{\mathrm{a}}$

\begin{tabular}{|c|c|c|c|c|c|c|}
\hline No. & Bacterial and fungal isolates & Source $^{b}$ & Geographic origin & IS1113 $^{c}$ & Siderophore $^{\mathrm{d}}$ & rhs Family gene $\mathrm{e}^{\mathrm{e}}$ \\
\hline 1 & Xanthomonas oryzae pv. oryzae & KACC 10331 & Republic of Korea & + & + & + \\
\hline 2 & X. oryzae pv. oryzae & KACC 10878 & Republic of Korea & - & + & + \\
\hline 3 & X. oryzae pv. oryzae & KACC 10381 & Republic of Korea & - & + & + \\
\hline 4 & X. oryzae pv. oryzae & KACC 10384 & Republic of Korea & + & + & + \\
\hline 5 & $X$. oryzae pv. oryzae & KACC 10385 & Republic of Korea & - & - & + \\
\hline 6 & X. oryzae pv. oryzae & KACC 10883 & Philippines & + & - & + \\
\hline 7 & $X$. oryzae pv. oryzae & KACC 10885 & Philippines & - & + & + \\
\hline 8 & X. oryzae pv. oryzae & MAFF 311018 & Japan & + & + & + \\
\hline 9 & $X$ oryzae pv. oryzae & MAFF 311019 & Japan & - & - & + \\
\hline 10 & $X$. oryzae pv. oryzicola & LMG 797 & Malaysia & - & - & - \\
\hline 11 & X. oryzae pv. oryzicola & LMG 657 & India & - & + & - \\
\hline 12 & $X$. campestris pv. campestris & ATCC 33913 & United Kingdom & - & - & - \\
\hline 13 & X. campestris pv. carotae & ATCC 10547 & United States & - & - & - \\
\hline 14 & $X$. campestris pv. glycines & LMG 7403 & Zambia & - & - & - \\
\hline 15 & X. campestris pv. pelargoni & DSMZ 50857 & Germany & - & - & - \\
\hline 16 & X. campestris pv. juglandis & DSMZ 1049 & United Kingdom & - & - & - \\
\hline 17 & X. campestris pv. malvacearum & DSMZ 1220 & Germany & - & - & - \\
\hline 18 & X. axonopodis pv. citri & KACC10443 & Republic of Korea & - & - & - \\
\hline 19 & $X$. axonopodis pv. dieffenbachiae & LMG 695 & Brazil & - & - & - \\
\hline 20 & X. axonopodis pv. vasculorum & LMG 901 & Mauritius & - & - & - \\
\hline 21 & $X$. axonopodis pv. begoniae & LMG 551 & United Kingdom & - & - & - \\
\hline 22 & X. axonopodis pv. phaseoli & LMG 7455 & Belgium & - & - & - \\
\hline 23 & X. axonopodis pv. phyllanthi & LMG 844 & Sudan & - & - & - \\
\hline 24 & $X$. axonopodis pv. aurantifolii & KACC 10161 & Not known & - & - & - \\
\hline 25 & X. axonopodis pv. vesicatoria & LMG 905 & Tonga & - & - & - \\
\hline 26 & $X$. translucens pv. phleipratensis & LMG 843 & United States & - & - & - \\
\hline 27 & $X$. translucens pv. cerealis & LMG 679 & United States & - & - & - \\
\hline 28 & $X$. translucens pv. hordei & LMG 882 & Canada & - & - & - \\
\hline 29 & X. arboricola pv. poinsettiicola & LMG 5403 & New Zealand & - & - & - \\
\hline 30 & X. cassavae & LMG 673 & Malawi & - & - & - \\
\hline 31 & X. cucurbitae & LMG 8662 & New Zealand & - & - & - \\
\hline 32 & $X$. theicola & LMG 8684 & Japan & - & - & - \\
\hline 33 & Pectobacterium carotovorum subsp. carotovorum & LMG 2435 & Italy & - & - & - \\
\hline 34 & Pseudomonas syringae pv. tomato & LMG 5093 & United Kingdom & - & - & - \\
\hline 35 & Escherichia coli $(\mathrm{O} 157: \mathrm{H} 7)$ & ATCC 35150 & Not known & - & - & - \\
\hline 36 & Fusarium oxysporum f. sp. dianthi & ATCC 11939 & Not known & - & - & - \\
\hline
\end{tabular}

a Symbols: + and - indicate species was detected or not detected, respectively.

${ }^{\mathrm{b}}$ KACC, Korean Agricultural Culture Collection, Republic of Korea (http://genebank.rda.go.kr); MAFF, Ministry of Agriculture, Forestry and Fisheries of Japan; LMG, Belgian Coordinated Collections of Microorganisms (BCCM); ATCC, American Type Culture Collection, United States; DSMZ, German Collection of Microorganisms and Cell Cultures.

${ }^{\mathrm{c}}$ Putative siderophore receptor (22).

${ }^{\mathrm{d}}$ According to Sakthivel et al. (16).

e Positions XOO114 and XOO290 correspond to GenBank accession no. NC_006834, gi|58579623:124816-125631.

Table 2. Sequences of the primers and probes used in this study

\begin{tabular}{llcccc}
\hline Primer, probe & \multicolumn{1}{c}{ Sequences $\left(\mathbf{5}^{\prime} \mathbf{3}^{\prime}\right)$} & $\begin{array}{c}\text { Annealing } \\
\text { temperature }\left({ }^{\circ} \mathbf{C}\right)\end{array}$ & $\begin{array}{c}\text { Amplicon } \\
\text { size (bp) }\end{array}$ & Gene or position & \multicolumn{1}{c}{ Reference } \\
\hline TXT & GTCAAGCCAACTGTGTA & 56 & 964 & IS1113 & 16 \\
TXT4R & CGTTCGCGCCACAGTTG & $\ldots$ & $\ldots$ & $\ldots$ & $\ldots$ \\
PF & GAATATCAGCATCGGCAACAG & 68 & 152 & Siderophore receptor & 22 \\
PR & TACCGGAGCTGCGCGTT & $\ldots$ & $\ldots$ & $\ldots$ & $\ldots$ \\
Probe & FAM-CATCGCCTGCTCGGCTACCAGC-TAMRA & $\ldots$ & $\ldots$ & $\ldots$ & $\ldots$ \\
XOO114F & GATCCGCTCGGTCGCAATGTG & 60 & 114 & $125476-125589^{\mathrm{b}}$ & This study (Real) $^{\mathrm{c}}$ \\
XOO114R & GGCTCGCCCCAGTCCGTCGTA & $\ldots$ & $\ldots$ & $\ldots$ & $\ldots$ \\
XOO290F & GCGCACCGAGTATTCCTA & 56 & 290 & $125169-125458^{\mathrm{b}}$ & $\ldots$ \\
XOO290R & CTTCGCCGGTCCAGATGA & $\ldots$ & $\ldots$ & $\ldots$ & $\ldots$ \\
\hline
\end{tabular}

${ }^{a}$ Putative siderophore receptor.

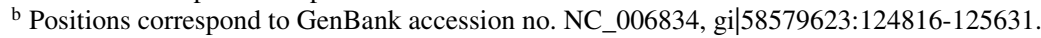

${ }^{\mathrm{c}}$ Real and Conv. $=$ real-time and conventional polymerase chain reaction. 
the amplification of putative siderophore receptor, the primers, probe, and reaction conditions were as described by Zhao et al. (21).

DNA dot-blot analysis. A total volume of $10 \mu \mathrm{l}$ of genomic DNA (approximately $100 \mathrm{ng}$ ) was spotted onto a Hybond-N+ nylon membrane (Amersham Pharmacia Biotech, UK) and then UV

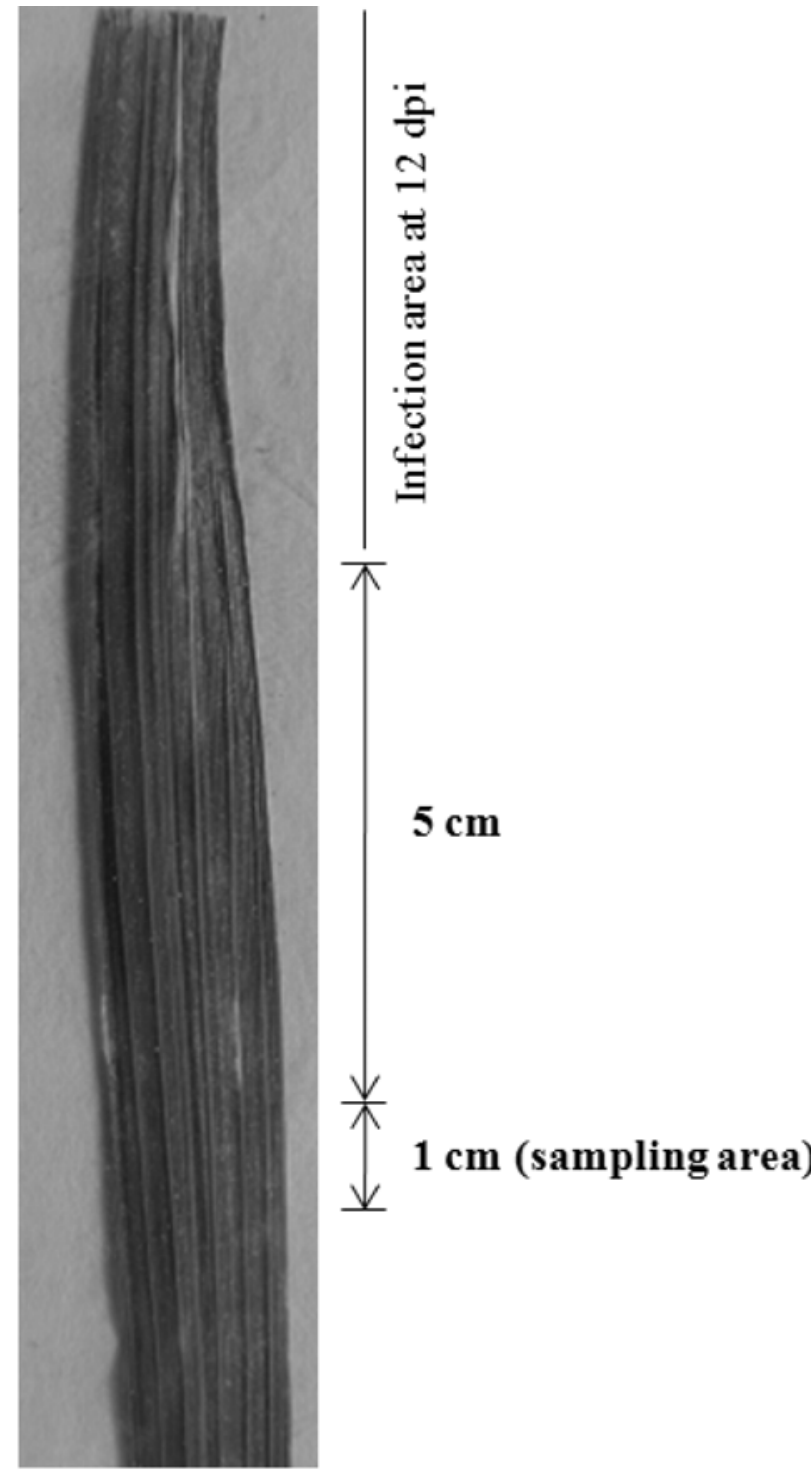

Fig. 1. Sampling area of rice leaves (Oryza sativa 'Dongjin'). Assays were performed using the leaf-clip method with Xanthomonas oryzae pv. oryzae KACC10331; dpi = days postinoculation. cross-linked to bind the labeled probe DNA, where the PCR product from $X$. oryzae pv. oryzae KACC10331 with the XOO114 primer set was labeled as a probe with $\left[{ }^{32} \mathrm{P}\right] \mathrm{dCTP}$ using the random primed method according to the manufacturer's instructions (Ladderman Labeling kit; Takara, Japan). The prehybridization and hybridization were performed in hybridization buffer $(0.75 \mathrm{M}$ $\mathrm{NaCl}, 75 \mathrm{mM}$ sodium citrate, $0.5 \%$ sodium dodecyl sulfate [SDS], $0.1 \%$ bovine serum albumin, $0.1 \%$ Ficoll, $0.1 \%$ polyvinylpyrrolidone, and denatured salmon sperm DNA at $50 \mu \mathrm{l} / \mathrm{ml}$ ) at $65^{\circ} \mathrm{C}$ for $18 \mathrm{~h}$. After hybridization, the membrane was performed at room temperature for $2 \times 10 \mathrm{~min}$ in $2 \times \mathrm{SSC}(1 \times \mathrm{SSC}$ is $0.15 \mathrm{M} \mathrm{NaCl}$ plus $0.015 \mathrm{M}$ sodium citrate) and $0.1 \%$ SDS and at $65^{\circ} \mathrm{C}$ for $2 \times 15$ min in $0.1 \times$ SSC and $0.1 \%$ SDS. Autoradiography was conducted at $-70^{\circ} \mathrm{C}$ with CURIX X-ray film (AGFA, Belgium).

Detection of pathogen by bio-PCR. $X$. oryzae pv. oryzae KACC10331 was grown on YGC medium and bacterial cells were adjusted to an optical density at $600 \mathrm{~nm}\left(\mathrm{OD}_{600}\right)=0.5$. Bacterial cells were inoculated on independent leaves of 3-week-old seedlings (Oryza sativa 'Dongjin') grown in a greenhouse by the leafclip method and the samples were taken from an area $5 \mathrm{~cm}$ from the lesion area shown at 12 days postinoculation (dpi) (Fig. 1). Each sample was dipped in $500 \mu \mathrm{l}$ of sterile distilled water for 30 min. Water treated with each sample $(2 \mu \mathrm{l})$ was used in SYBR Green real-time and conventional PCR assays as described above.

\section{Results}

Sequence specificity of designed primers. The specificity of the primer sets based on the rhs family gene of $X$. oryzae pv. oryzae KACC10331 (GenBank accession no. NC_006834, gi|58579623:124816-125631) was tested in silico by a similarity search against the National Center for Biotechnology Information BLAST sequence database (http://www.ncbi.nlm.nih.gov/). There were no significant matches with previously determined sequences.

Specificity test of primers. The primer set XOO290F/R was tested by conventional PCR against $X$. oryzae pv. oryzae. As expected, a 290-bp DNA fragment was amplified (Fig. 2). To check the specificity of the primers, a large collection of other microorganisms, including other Xanthomonas spp. and their pathovars, was tested by SYBR Green real-time PCR with the XOO114F/R primer set. DNA from the other Xanthomonas strains and reference microorganisms was not successfully amplified with these primers; only assays with $X$. oryzae pv. oryzae yielded amplified products with fluorescence intensity and a single amplified DNA fragment (Table 1).

Standard curves and melting temperature. We used SYBR Green real-time PCR analysis of X. oryzae pv. oryzae to generate a standard curve by plotting the mean cycle threshold $(n=3)$ versus the logarithmic concentration of genomic DNA, cloned DNA, and density of the cell suspension (range, $5 \times 10^{0}$ to $5 \times 10^{-6} \mathrm{ng} / \mu \mathrm{l}$, $1.45 \times 10^{9}$ to $1.45 \times 10^{3} \mathrm{copies} / \mu \mathrm{l}$, and $0.1 \times 10^{0}$ to $0.1 \times 10^{-6}$ $\mathrm{OD}_{600}$ unit of cells, respectively; Fig. 3A; Table 3). The assay exhibited a good linear response $\left(R^{2}=0.994\right)$. The detection limit

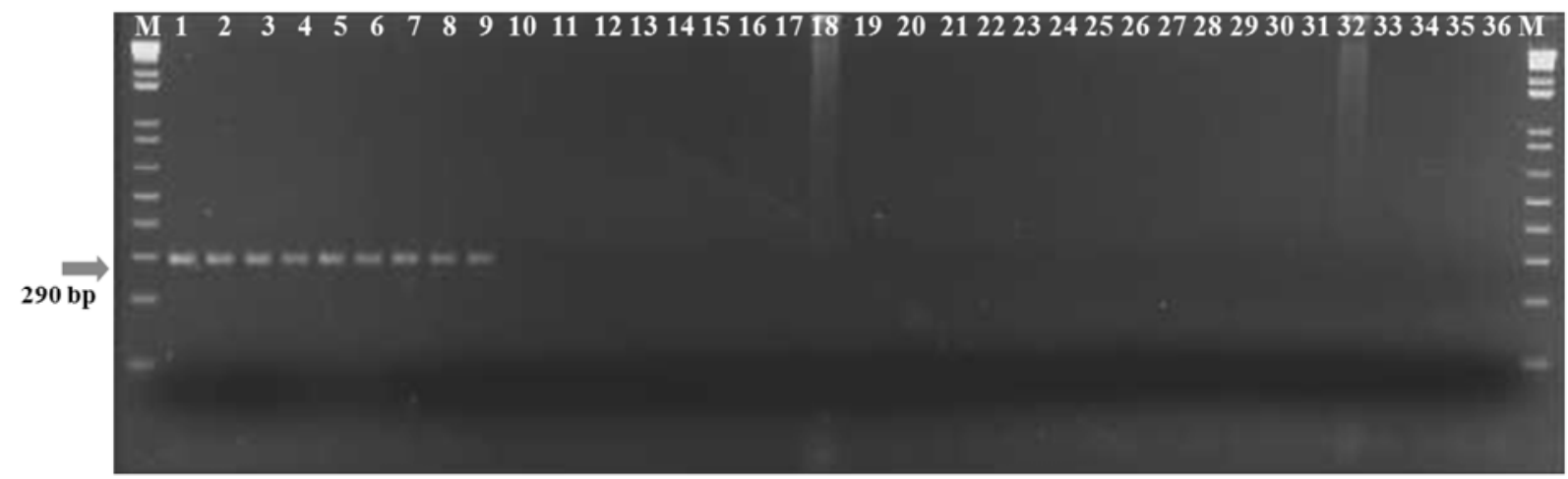

Fig. 2. Specific polymerase chain reaction amplification of an rhs family gene fragment from Xanthomonas oryzae pv. oryzae with the primer set XOO290F/R. Lane M, size marker (1-kb DNA plus ladder; Gibco BRL); lanes 1-36 are listed in Table 1. 
of the reaction was one cloned copy of the rhs family gene of $X$. oryzae pv. oryzae. Standard regression analysis of the linear part of the slope gave a coefficient of -3.311 , which yielded a PCR efficiency of $100.4 \%$ (Fig. 3B). Analysis of the melting temperature and melting peaks of $X$. oryzae pv. oryzae by SYBR Green realtime PCR revealed a reproducible melting temperature of $85^{\circ} \mathrm{C}$ and specific peaks (Fig. 3C).

DNA dot-blot analysis. The presence of the rhs family gene or of homologs in Xanthomonas strains was confirmed by dot-blot analysis. All strains of $X$. oryzae pv. oryzae hybridized with a PCR probe (XOO114) specific to the rhs family gene. This result suggested that the rhs family gene is highly conserved in X. oryzae pv. oryzae (Fig. 4). Assays with DNA from strains of other Xanthomonas spp. and other phytopathogens showed no hybridizing signal, indicating that the rhs family gene does not exist or is not substantially homologous in other bacteria and fungi.

Detection of the pathogen by bio-PCR in infected rice. Each primer set, XOO114F/R and XOO290F/R, could also detect the pathogen by SYBR Green real-time and conventional PCR in infected rice leaves. Amplified products derived from all infected rice leaves showed fluorescence in the SYBR Green real-time PCR assay, and the expected fragment size of approximately 290 bp was amplified by conventional PCR, whereas no band was amplified from healthy rice leaf samples (Fig. 5).
A

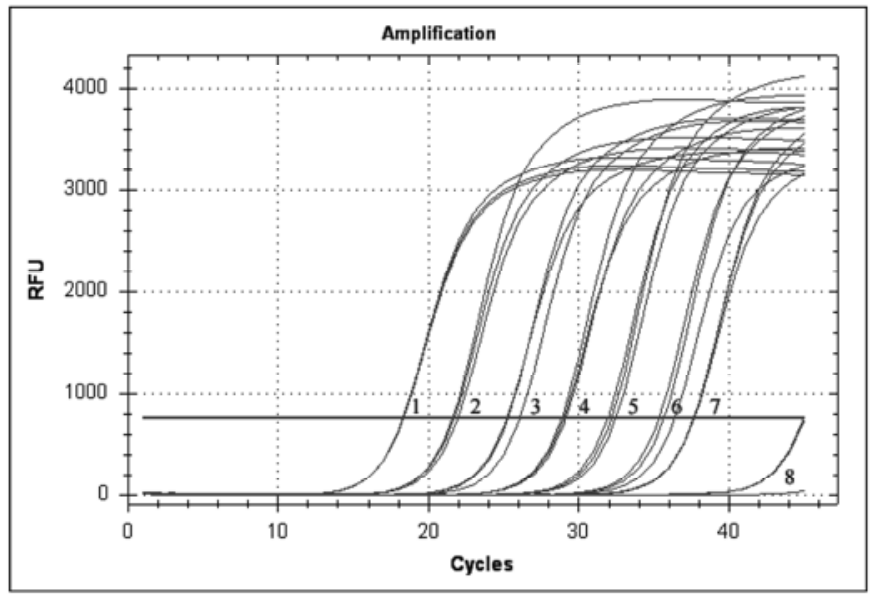

B

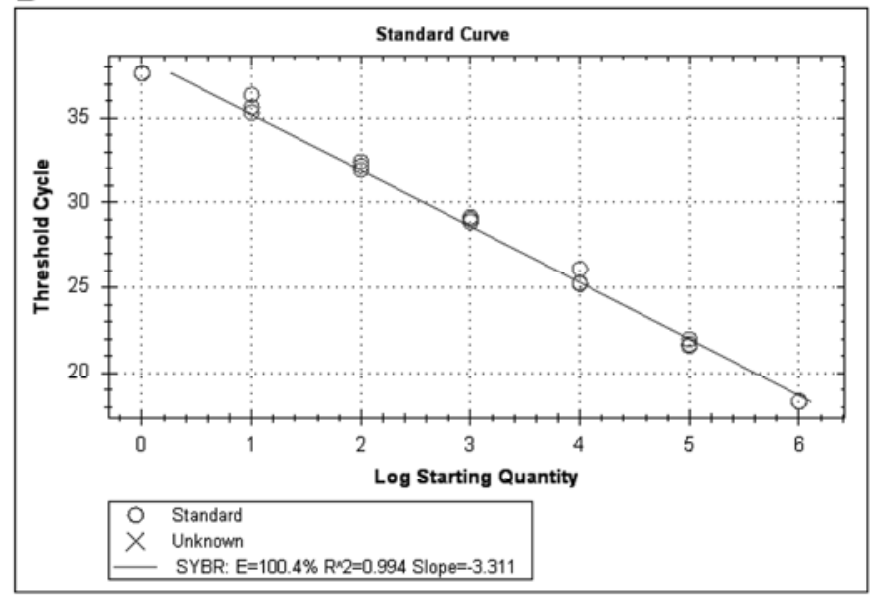

C

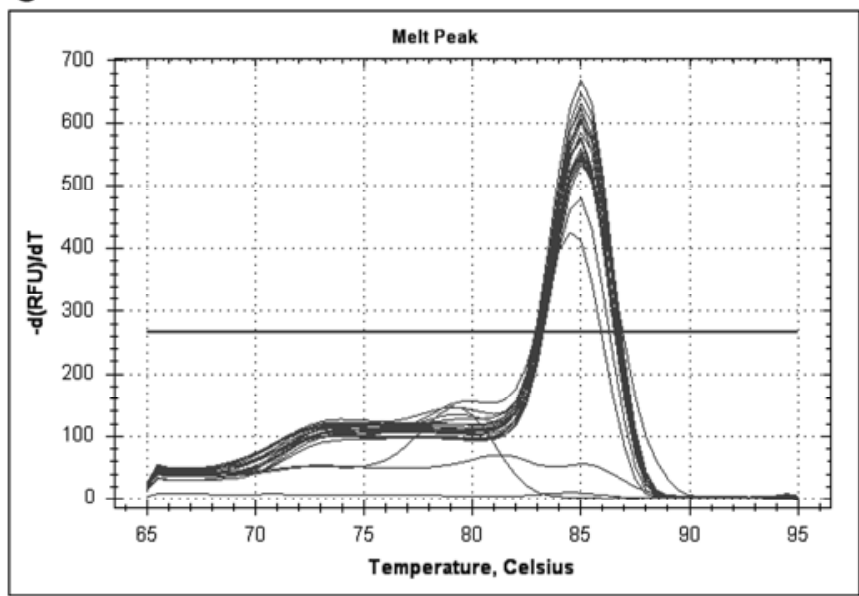

Fig. 3. Specificity, melting peak, and standard curve of the XO0114F/R primer set using SYBR Green real-time polymerase chain reaction (PCR). A, Fluorescence intensity as a function of concentration of template. For each assay, a series of 10-fold dilutions of cloned DNA (range, $1.45 \times 10^{9}$ to $1.45 \times 10^{3}$ copies/ $/$ l) was used as the template for PCR ( $1-$ 7, sample dilutions; 8, no template control). B, Standard curve derived from the amplification plot. C, Melting-peak analysis. The negative first derivative of relative fluorescence units $(-d(R F U) / d T)$ is plotted as a function of temperature. Amplified product, $85^{\circ} \mathrm{C}$. A high peak indicates amplified product and a low peak is the no-template control.

Table 3. Mean cycle threshold $\left(\mathrm{C}_{\mathrm{T}}\right)$ end-point fluorescence of 10-fold serial dilutions of Xanthomonas oryzae pv. oryzae cloned DNA, genomic DNA, and cell suspension as determined by the SYBR Green real-time polymerase chain reaction assay

\begin{tabular}{|c|c|c|c|c|c|}
\hline \multicolumn{2}{|l|}{ Cloned DNA } & \multicolumn{2}{|c|}{ Genomic DNA } & \multicolumn{2}{|c|}{ Cell suspension } \\
\hline Plasmid copies/ $\mu \mathrm{l}$ & $\mathrm{C}_{\mathrm{T}}$ values & Weight/ $\mu \mathrm{l}$ & $\mathrm{C}_{\mathrm{T}}$ values & Cell density ${ }^{a}$ & $\mathrm{C}_{\mathrm{T}}$ values \\
\hline $1.45 \times 10^{9}$ & $18.32 \pm 0.02$ & $5 \mathrm{ng}$ & $17.45 \pm 0.19$ & $0.1 \times 10^{0}$ & $18.27 \pm 0.22$ \\
\hline $1.45 \times 10^{8}$ & $21.75 \pm 0.22$ & $500 \mathrm{pg}$ & $20.55 \pm 0.34$ & $0.1 \times 10^{-1}$ & $19.28 \pm 0.14$ \\
\hline $1.45 \times 10^{7}$ & $25.52 \pm 0.56$ & $50 \mathrm{pg}$ & $24.15 \pm 0.15$ & $0.1 \times 10^{-2}$ & $22.56 \pm 0.08$ \\
\hline $1.45 \times 10^{6}$ & $29.02 \pm 0.14$ & $5 \mathrm{pg}$ & $27.54 \pm 0.24$ & $0.1 \times 10^{-3}$ & $26.30 \pm 0.11$ \\
\hline $1.45 \times 10^{5}$ & $32.19 \pm 0.25$ & $500 \mathrm{fg}$ & $30.95 \pm 0.29$ & $0.1 \times 10^{-4}$ & $30.14 \pm 0.09$ \\
\hline $1.45 \times 10^{4}$ & $35.78 \pm 0.59$ & $50 \mathrm{fg}$ & $33.91 \pm 0.84$ & $0.1 \times 10^{-5}$ & $33.76 \pm 0.43$ \\
\hline $1.45 \times 10^{3}$ & $37.65 \pm 0.03$ & $5 \mathrm{fg}$ & $37.82 \pm 0.85$ & $0.1 \times 10^{-6}$ & $36.97 \pm 0.61$ \\
\hline
\end{tabular}

a Optical density at $600 \mathrm{~nm}$ unit of cells. 


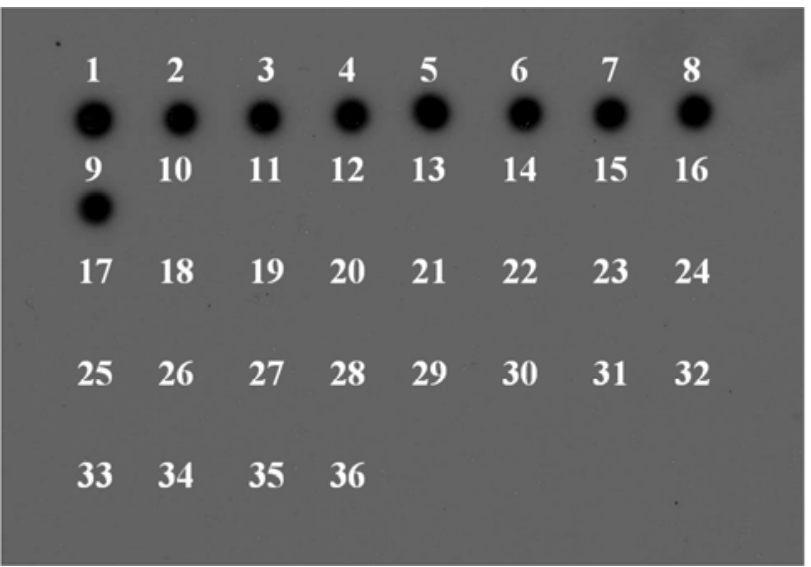

Fig. 4. DNA dot-blot analysis of the rhs family gene with a polymerase chain reaction-amplified fragment (114 bp) from Xanthomonas oryzae pv. oryzae. Lanes 1-9, $X$. oryzae pv. oryzae; lanes 10-36, other reference microbes (listed in Table 1).

\section{Discussion}

Detection of a pathogen in nonsymptomatic seedlings is of importance in certification programs for both domestic and international quarantine because a latent population can lead to serious epidemics under favorable conditions. Early detection of diseases is important for assessing the health status of a rice nursery before the transplantation of seedlings to fields.

Recently, development of specific primers and DNA probes from the $16 \mathrm{~S}-23 \mathrm{~S}$ rDNA spacer region, repeated elements, and siderophore receptor for identification and detection has been reported for $X$. oryzae pv. oryzae $(16,21)$. However, it has been revealed that these gene regions are insufficient to discriminate between pathovars of $X$. oryzae in this study because insertion sequence (IS) may undergo periodic extinction in prokaryotic genomes, which are detrimental to their host in the long run, and others are highly conserved in genomes as a level of species $(13,18)$.

A bioinformatics method was used to search specific target sequences for the PCR detection of bacterial pathogens such as a

A
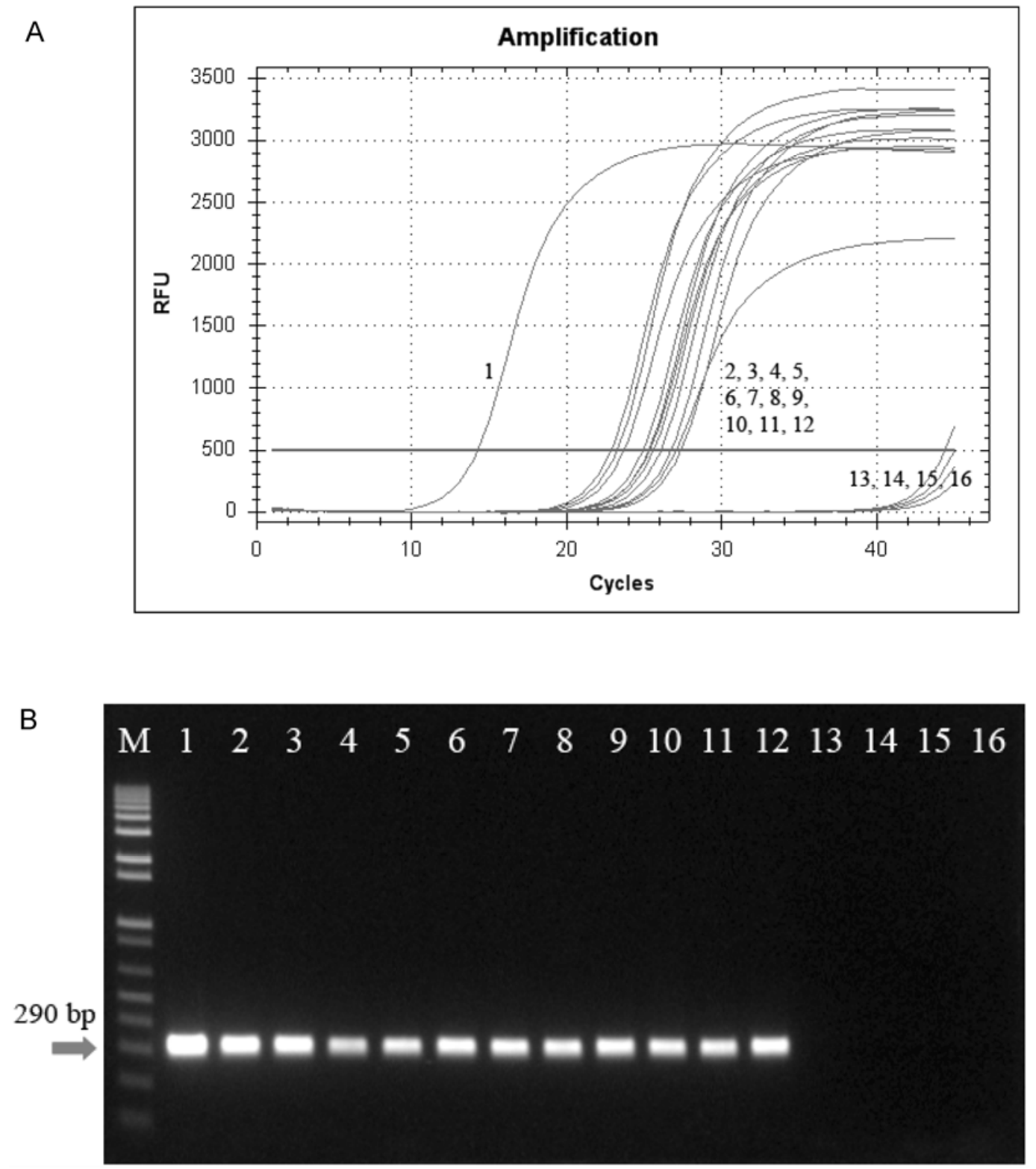

Fig. 5. Specific detection of Xanthomonas oryzae pv. oryzae by SYBR Green real-time and conventional polymerase chain reaction (PCR) in infected rice leaves using the primer sets A, X00114F/R and B, XOO290F/R, respectively. A, Fluorescence intensity corresponding to rhs family gene sequences from X. oryzae pv. oryzae amplified using XO0114F/R. 1, X. oryzae pv. oryzae KACC10331 genomic DNA; 2-12, inoculated rice leaves; 13-15, healthy rice leaves; 16 , no-template control. B, PCR amplification of the rhs family gene from X. oryzae pv. oryzae using the XOO290F/R primers. Lane M, size marker (1-kb DNA plus ladder; Gibco BRL); lane 1, X. oryzae pv. oryzae KACC10331 gDNA; lanes 2-12, inoculated rice leaves; lane 13-15, healthy rice leaves; lane 16, negative control (distilled water). 
genome comparing candidate genes with other bacterial DNA genomic sequences by implementing BLAST (22). We found the specific sequence region by sequence alignment search and the rhs family genes of Xanthomonas and Pectobacterium spp. using BLAST and electronic PCR (e-PCR) analysis $(11,12)$. Rhs elements were first described in Escherichia coli (8); however, their function is as yet unclear. Rhs genes are ubiquitous and comprise six structurally distinct lineages within the Enterobacteriaceae family. There is considerable intergenomic variation in rhs repertoire (4). The RhsA core, representative of the Rhs ABC subfamily, diverges by $22 \%$ from the $R h s \mathrm{D}$ core, representative of the RhsD-E subfamily (15).

Therefore, in this study, a real-time PCR assay for the detection of $X$. oryzae pv. oryzae based on the rhs family genes was developed. The results of this study showed that the rhs family genederived primer pair which has been shown to be specific for $X$. oryzae pv. oryzae was amplified (Figs. 2, 4, and 5).

In conclusion, this study indicated that these primer sets are highly specific for $X$. oryzae pv. oryzae and that a rhs family gene real-time PCR assay can be used as a reliable and useful method for the detection and diagnosis of this pathogen.

\section{Acknowledgments}

Project funding was from the Rural Development Administration, Republic of Korea.

\section{Literature Cited}

1. Adachi, N., and Oku, T. 2000. PCR-mediated detection of Xanthomonas oryzae pv. oryzae by amplification of the $16 \mathrm{~S}-23 \mathrm{~S}$ rDNA spacer region sequence. J. Gen. Plant Pathol. 66:303-309.

2. Benedict, A. A., Alvarez, A. M., Berstecky, J., Imanaka, W., Mizumoto, C. Y., Pollard, L. W., Mew, T. W., and Gonzalez, C. F. 1989. Pathovar-specific monoclonal antibodies for Xanthomonas campestris pv. oryzae and for Xanthomonas oryzae pv. oryzicola. Phytopathology 79:322-326.

3. Chase, A. R., Stall, R. E., Hodge, N. C., and Jones, J. B. 1992. Characterization of Xanthomonas campestris strains from aroids using physiological, pathological and fatty acid analyses. Phytopathology 82:754-759.

4. Jackson, A. P., Thomas, G. H., Parkhill, J., and Thomson, N. R. 2009. Evolutionary diversification of an ancient gene family (rhs) through Cterminal displacement. BMC Genomics 10:584-599.

5. Jones, J. B., Chase, A. R., and Harris, G. K. 1993. Evaluation of the Biology GN MicroPlate system for identification of some plant-pathogenic bacteria. Plant Dis. 77:553-558.

6. Lazo, G. R., and Gabriel, D. W. 1987. Conservation of plasmid DNA sequences and pathovar identification of strains of Xanthomonas campestris. Phytopathology 77:448-453.

7. Liao, X., Zhu, S., Zhao, W., Luo, K., and Qi, Y. 2003. Detection and identification of Xanthomonas oryzae pv. oryzae and Xanthomonas oryzae pv. oryzicola by real-time fluorescent PCR. Wei Sheng Wu Xue Bao 43:626-634.

8. Lin, R. J., Capage, M., and Hill, C. W. 1984. A repetitive DNA sequence, rhs, responsible for duplications within the Escherichia coli K-12 chromosome. J. Mol. Biol. 177:1-18.

9. Mew, T. W. 1987. Current status and future prospects of research on bacterial blight of rice. Annu. Rev. Phytopathol. 25:359-382.

10. Mew, T. W., Vera Cruz C. M., and Medalla, E. S. 1992. Changes in race frequency of Xanthomonas oryzae pv. oryzae in response to rice cultivars planted in the Philippines. Plant Dis. 76:1029-1032.

11. Park, D. S., Shim, J. K., Kim, J. S., Kim, B. Y, Kang, M. J., Seol, Y. J., Hahn, J. H., Shrestha, R., Lim, C. K., Go, S. J., and Kim, H. G. 2006. PCRbased sensitive and specific detection of Pectobacterium atrosepticum using primers based on $r h s$ family gene sequences. Plant Pathol. 55:625-629.

12. Park, D. S., Shim, J. K., Kim, J. S., Lim, C. K., Shrestha, R., Hahn, J. H., and Kim, H. G. 2009. Sensitive and specific detection of Xanthomonas campestris pv. vesicatoria by PCR using pathovar-specific primers based on $r h s$ family gene sequences. Microbiol. Res. 164:36-42.

13. Raaijmakers, J. M., Bitter, W., Punte, H. L., Bakker, P. A., Weisbeek, P. J., and Schippers, B. 1994. Siderophore receptor PupA as a marker to monitor wild-type Pseudomonas putida WCS358 in natural environments. Appl Environ. Microbiol. 60:1184-1190.

14. Raina, G. L., Sidhu, G. S., and Saini, P. K. 1982. Rice bacterial blight status in Punjab, India. Rev. Plant Pathol. 61:49-62.

15. Sadosky, A. B., Gray, J. A., and Hill, C. W. 1991. The RhsD-E subfamily of Escherichia coli K-12. Nucleic Acids Res. 19:7177-7183.

16. Sakthivel, N., Mortensen, C. N., and Mathur, S. B. 2001. Detection of Xanthomonas oryzae pv. oryzae in artificially inoculated and naturally infected rice seeds and plants by molecular techniques. Appl. Microbiol. Biotechnol. 56:435-441.

17. Sambrook, J., Fritsch, E. F., and Maniatis, T. 1989. Molecular Cloning: A Laboratory Manual, 2nd ed. Cold Spring Harbor Laboratory Press, Cold Spring Harbor, NY.

18. Siguier, P., Filee, J., and Chandler, M. 2006. Insertion sequences in prokaryotic genomes. Curr. Opin. Microbiol. 9:526-531.

19. Vera Cruz, C. M., Gossele, F., Kersters, K., Segers, P., Van den Mooter, M., Swings, J., and De Ley, J. 1984. Differentiation between Xanthomonas campestris pv. oryzae, Xanthomonas oryzae pv. oryzicola and the bacterial brown blotch pathogen on rice by numerical analysis of phenotypic features and protein gel electrophoregrams. J. Gen. Microbiol 130:2983-2999.

20. Whelan, J. A., Russel, N. B., and Whelan, M. A. 2003. A method for the absolute quantification of cDNA using real time PCR. J. Immunol. Methods 278:261-269.

21. Zhao, W. J., Zhu, S. F., Liao, X. L., Chen, H. Y., and Tan, T. W. 2007. Detection of Xanthomonas oryzae pv. oryzae in seeds using a specific TaqMan probe. Mol. Biotechnol. 35:119-127.

22. Zhu, D. S., Zho, M., Fan, Y. L., and Shi, X. M. 2009. Identification of new target sequences for PCR detection of Vibrio parahaemolyticus by genome comparison. J. Rapid Methods Automat. Microbiol. 17:67-79. 